Article

\title{
Involvement of Receptor for Advanced Glycation Endproducts in Hypertensive Disorders of Pregnancy
}

\author{
Juria Akasaka ${ }^{1}$, Katsuhiko Naruse ${ }^{1}$, Toshiyuki Sado ${ }^{1}$, Tomoko Uchiyama ${ }^{2}$, Mai Makino ${ }^{2}$, \\ Akiyo Yamauchi ${ }^{2}$, Hiroyo Ota ${ }^{2}$, Sumiyo Sakuramoto-Tsuchida ${ }^{2}$, Asako Itaya-Hironaka ${ }^{2}$, \\ Shin Takasawa ${ }^{2, *(D)}$ and Hiroshi Kobayashi ${ }^{1}$ \\ 1 Department of Obstetrics and Gynecology, Nara Medical University, 840 Shijo-cho, Kashihara, \\ Nara 634-8522, Japan; juria@naramed-u.ac.jp (J.A.); naruse@naramed-u.ac.jp (K.N.); \\ tsado@naramed-u.ac.jp (T.S.); hirokoba@nmu-gw.naramed-u.ac.jp (H.K.) \\ 2 Department of Biochemistry, Nara Medical University, 840 Shijo-cho, Kashihara, Nara 634-8521, Japan; \\ uchiyama0403@naramed-u.ac.jp (T.U.); m.makino@naramed-u.ac.jp (M.M.); \\ yamauchi@naramed-u.ac.jp (A.Y.); hiroyon@naramed-u.ac.jp (H.O.); ssumiyo@naramed-u.ac.jp (S.S.-T.); \\ iasako@naramed-u.ac.jp (A.I.-H.) \\ * Correspondence: shintksw@naramed-u.ac.jp; Tel.: +81-744-22-3051 (ext. 2227); Fax: +81-744-24-9525
}

Received: 29 August 2019; Accepted: 28 October 2019; Published: 1 November 2019

\begin{abstract}
Preeclampsia/hypertensive disorders of pregnancy (PE/HDP) is a serious and potentially life-threatening disease. Recently, PE/HDP has been considered to cause adipose tissue inflammation, but the detailed mechanism remains unknown. We exposed human primary cultured adipocytes with serum from PE/HDP and healthy controls for $24 \mathrm{~h}$, and analyzed mRNA expression of several adipokines, cytokines, and ligands of the receptor for advanced glycation endproducts (RAGE). We found that the mRNA levels of interleukin-6 (IL-6), C-C motif chemokine ligand 2 (CCL2), high mobility group box 1 (HMGB1), and RAGE were significantly increased by the addition of PE/HDP serum. Among RAGE ligands, advanced glycation endproducts (AGE) and HMGB1 increased mRNA levels of IL-6 and CCL2 in SW872 human adipocytes and mouse 3T3-L1 cells. The introduction of small interfering RNA for RAGE (siRAGE) into SW872 cells abolished the AGE- and HMGB1-induced up-regulation of IL-6 and CCL2. In addition, lipopolysaccharide (LPS), a ligand of RAGE, increased the expression of IL- 6 and CCL2 and siRAGE attenuated the LPS-induced expression of IL-6 and CCL2. These results strongly suggest that the elevated AGE, HMGB1, and LPS in pregnant women up-regulate the expression of IL-6 and CCL2 via the RAGE system, leading to systemic inflammation such as PE/HDP.
\end{abstract}

Keywords: hypertensive disorders of pregnancy; RAGE; AGE; adipocyte; IL-6; CCL2; LPS

\section{Introduction}

Preeclampsia/hypertensive disorders of pregnancy (PE/HDP) is a serious and potentially lifethreatening disease appearing as a complication in about $2-12 \%$ of all pregnancies and associated with significant perinatal and maternal mortality [1,2]. It is estimated that more than 60,000 women worldwide die of the disease each year; it is one of the main causes of maternal mortality [3]. There is considerable evidence that maternal obesity, increased insulin resistance, inflammation, and aberrant fatty acid metabolism are involved in the pathogenesis of PE/HDP [4,5]. Inflammatory reactions have recently been attracting attention as the pathophysiological characteristics of PE/HDP, including vascular endothelial dysfunction and placental abnormalities [6-14]. Shallow trophoblast invasion and inadequate artery remodeling in pregnancy may cause placental hypoperfusion, hypoxia, or ischemia, which play an important role in the pathogenesis of PE/HDP [15]. The link between adiposity, 
inflammation, and insulin resistance has been increasingly acknowledged since Spiegelman and his colleagues demonstrated the relationship [16]. White adipose tissue secretes pro-inflammatory cytokines which contribute significantly to the chronic inflammatory state and metabolic complications of obesity [17]. It is plausible that similar disturbances in adipocyte function might contribute to the development of the clinical syndrome of PE/HDP, a state of inflammation and insulin resistance.

Adipose tissue, complex tissue composed of preadipocytes, adipocytes, and stromal vascular cells, is one of the representative organs to contribute to worsening insulin resistance through inflammation and subsequent dysfunction. Visceral adiposity correlates with metabolic risk factor [18] and adverse metabolic outcomes in pregnancy including gestational diabetes mellitus and PE/HDP [19-21]. Adipokines are cytokines expressed in and secreted from adipocytes in response to the systemic nutritional status, and some of them induce macrophage infiltration and inflammatory cytokine secretion [22,23]. In the present study, we analyzed expression of adipokines including inflammatory cytokines in adipocytes and found the involvement of receptor for advanced glycation endproducts (RAGE) in expression of interleukin-6 (IL-6) and C-C motif chemokine ligand 2 (CCL2) in adipocytes.

\section{Results}

2.1. PE/HDP Patient Sera Up-Regulated Gene Expression of IL-6, CCL2, High Mobility Group Box (HMGB)1, S100 $\mathrm{Ca}^{2+}$-Binding Protein B (S100B), and Receptor for Advanced Glycation Endproducts (RAGE) in Primary Cultured Human Adipocytes

Obesity increases PE/HDP risk. Maternal obesity, increased insulin resistance, and inflammation are involved in the pathogenesis of PE/HDP [24,25]. Furthermore, PE/HDP risk has been reported to increase 2-4-fold among women with diabetes [26]. We therefore hypothesized that the PE/HDP patient sera contain some of these factors that induce insulin resistance and/or inflammation. We incubated primary cultured human adipocytes with sera from disease-free pregnant women (control) or those from PE/HDP (patients) for $24 \mathrm{~h}$, and the gene expression of IL-6, CCL2, tumor necrosis factor $\alpha$ (TNF $\alpha)$, leptin (LEP), adiponectin (ADIP), resistin (RETN), HMGB1, S100B, and RAGE in the adipocytes was measured via real-time reverse transcriptase-polymerase chain reaction (RT-PCR). As shown in Figure 1, mRNA levels of IL-6, CCL2, HMGB1, S100B, and RAGE, but not TNF $\alpha, L E P, A D I P$, and RETN $(P=0.4496, P=0.1157, P=0.0875$, and $P=0.2912$, respectively) were significantly increased by the addition of $\mathrm{PE} / \mathrm{HDP}$ patient sera compared to those cells incubated with control sera.

\subsection{Up-Regulation of IL-6 and CCL2 by HMGB1 and Advanced Glycation Endproducts (AGE) in Adipocytes}

It is well-known that HMGB1 and S100B are typical ligands for RAGE. RAGE expression was reported in adipocytes and SW872 cells $[27,28]$, and furthermore immunofluorescent staining of RAGE in 3T3-L1 adipocytes was shown [27]. RAGE expression was up-regulated by ligands for RAGE [29], we tested whether ligands for RAGE up-regulate gene expression of inflammatory mediators, such as IL-6 and CCL2, in human SW872 adipocytes. We added HMGB1, AGE, and S100B in SW872 culture medium, incubated for $24 \mathrm{~h}$, and the expression of $I L-6$ and CCL2 was analyzed via real-time RT-PCR. As shown in Figure 2, mRNAs of $I L-6$ and CCL2 were significantly up-regulated by the addition of HMGB1 and AGE. In contrast, S100B, another noted ligand for RAGE, failed to up-regulate mRNA for IL-6 or CCL2.

In order to see whether the up-regulation of mRNAs for IL-6 and Ccl2 occurred only in SW872 or other adipocytes, we cultured mouse 3T3-L1 preadipocytes, differentiated them into differentiated adipocytes, and tested whether ligands for RAGE up-regulate gene expression of $I L-6$ and $C c l 2$ in mouse 3T3-L1 undifferentiated preadipocytes and differentiated adipocytes. As shown in Figure 3, the mRNA levels of $I L-6$ were significantly up-regulated by AGE and HMGB1 but not by S100B $(P=0.6414)$ in differentiated 3T3-L1 adipocytes, but unchanged by any of the RAGE ligands (AGE, HMGB1, or S100B) in undifferentiated preadipocytes $(P=0.8037$ [No addition vs. AGE], $P=0.4793$ [No addition vs. HMGB1], and $P=0.3138$ [No addition vs. S100B]). In contrast, the mRNA levels of 
Ccl2 remained unchanged in response to AGE, HMGB1, or S100B in 3T3-L1 differentiated adipocytes $(P=0.1892$ [No addition vs. AGE], $P=0.2885$ [No addition vs. HMGB1], and $P=0.4024$ [No addition vs. S100B]), but significantly up-regulated in the undifferentiated preadipocytes by the addition of AGE but not by HMGB1 and S100B ( $P=0.1241$ [No addition vs. HMGB1] and $P=0.4305$ [No addition vs. S100B]) (Figure 3). Previous studies reported that S100B up-regulated TNF $\alpha$ in adipocytes [30,31]. In contrast, S100B induced neither IL-6 nor CCL2 in adipocytes in this study, suggesting that SW872 and 3T3-L1 cells may insensitive to S100B.
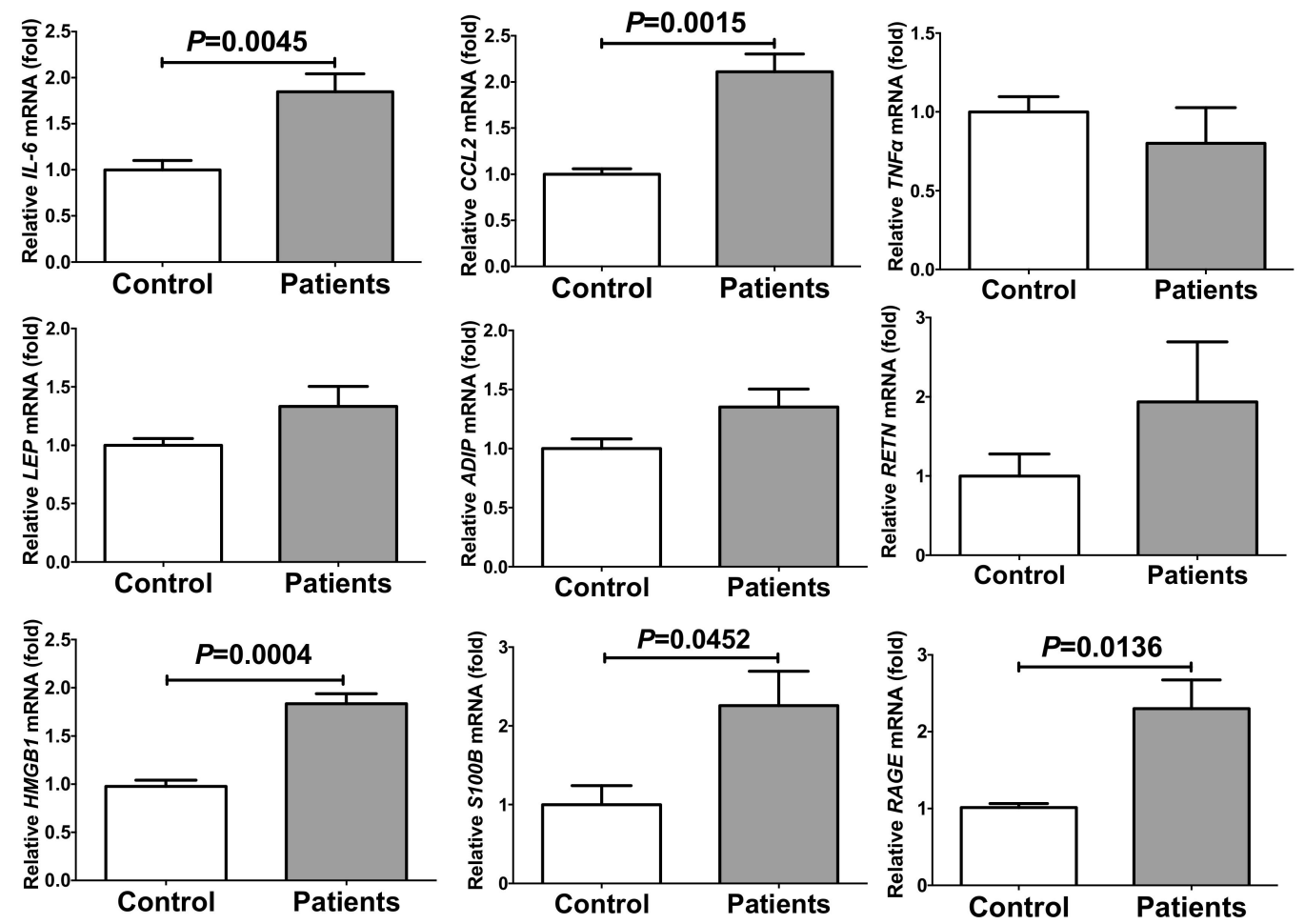

Figure 1. The mRNA levels of IL-6, CCL2, TNF $\alpha, L E P, A D I P, R E T N, H M G B 1, S 100 B$, and RAGE in primary cultured human adipocytes treated with sera from disease-free control (Control) or preeclampsia/hypertensive disorders of pregnancy (PE/HDP) patients (Patients) for $24 \mathrm{~h}$. The levels of the mRNAs were measured via real-time reverse transcriptase-polymerase chain reaction (RT-PCR) using $\beta$-actin as an endogenous control. Data are expressed as mean \pm SE for each group $(n=4)$. The statistical analyses were performed using Student's $t$-test.
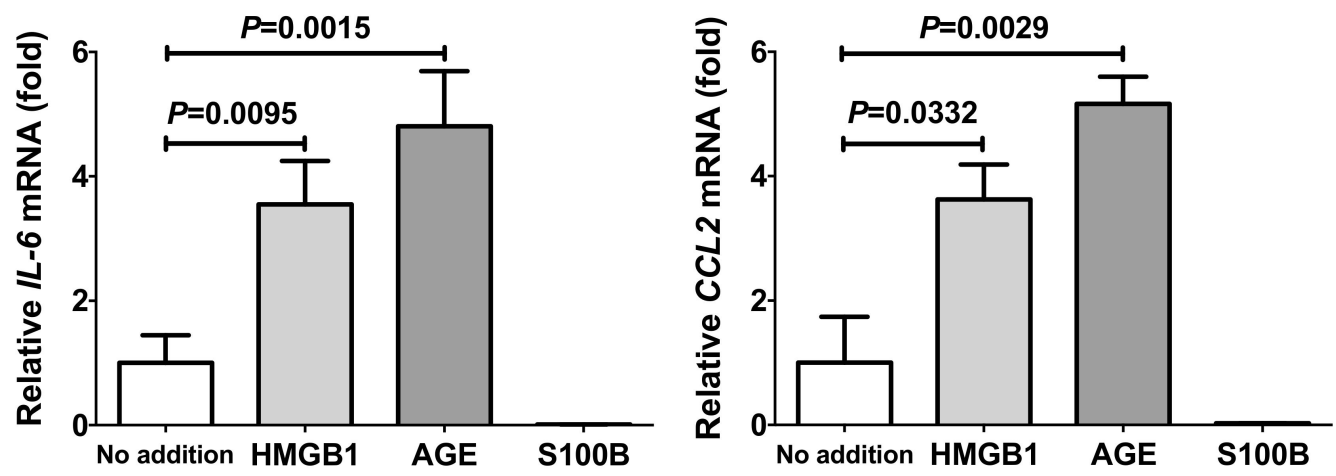

Figure 2. The mRNA levels of $I L-6$ and CCL2 in SW872 human adipocytes treated with $1 \mu \mathrm{g} / \mathrm{mL}$ HMGB1, $150 \mu \mathrm{g} / \mathrm{mL}$ advanced glycation endproducts (AGE), or $100 \mathrm{ng} / \mathrm{mL} \mathrm{S100B}$ for $24 \mathrm{~h}$. The levels of the mRNAs were measured via real-time RT-PCR using $\beta$-actin as an endogenous control. Data are expressed as mean \pm SE for each group $(n=4)$. The statistical analyses were performed using Student's $t$-test vs. No addition. 

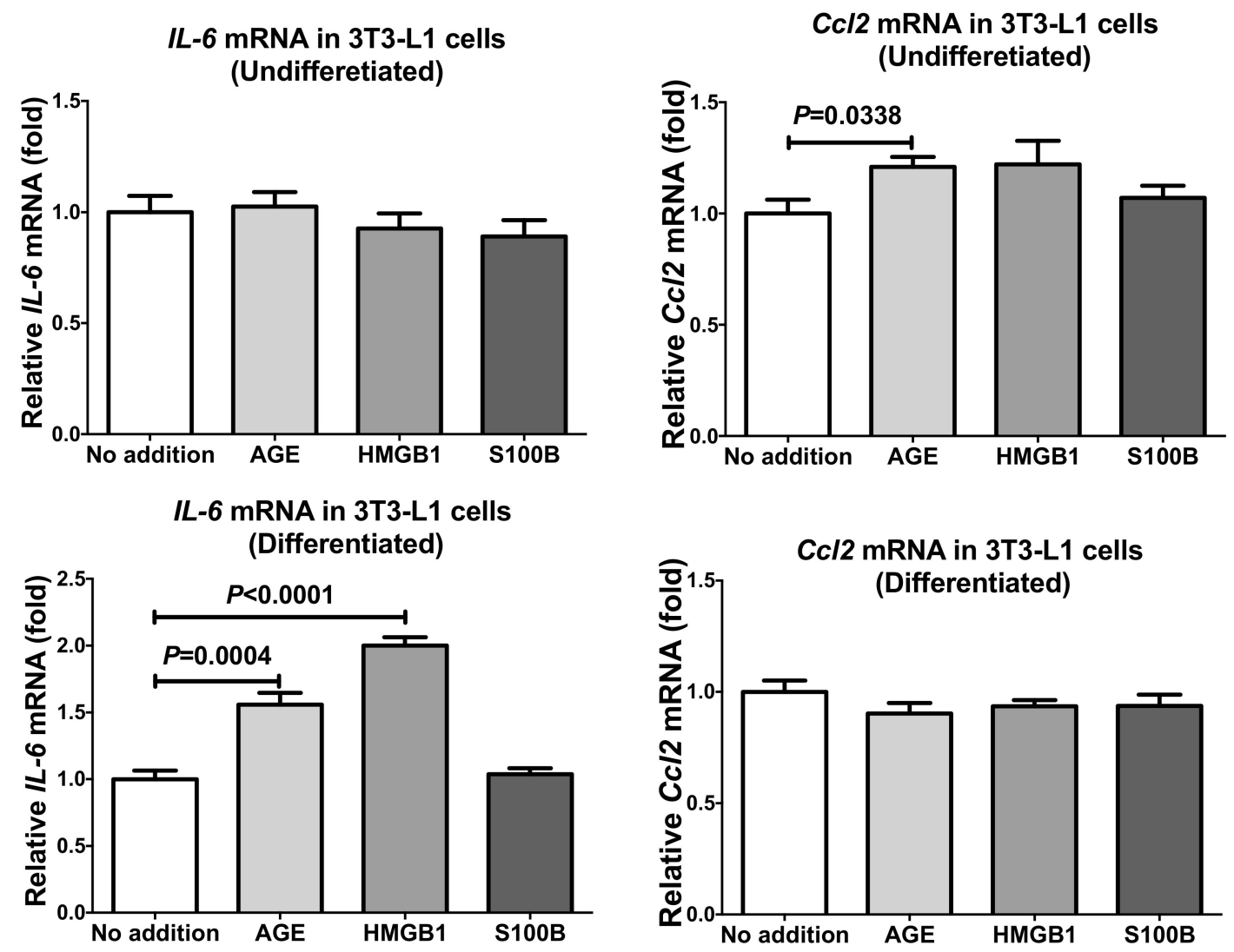

Figure 3. The mRNA levels of $I L-6$ and Ccl2 in 3T3-L1 mouse cells (undifferentiated preadipocytes and differentiated adipocytes) treated with $300 \mu \mathrm{g} / \mathrm{mL}$ AGE, $1 \mu \mathrm{g} / \mathrm{mL}$ HMGB1, or $100 \mathrm{ng} / \mathrm{mL}$ S100B for $24 \mathrm{~h}$. The levels of the mRNAs were measured via real-time RT-PCR using rat insulinoma gene (Rig)/ribosomal protein S15 (RpS15) as an endogenous control. Data are expressed as mean \pm SE for each group $(n=4)$. The statistical analyses were performed using Student's $t$-test vs. No addition.

2.3. Down-Regulation of RAGE Attenuated the Increases of IL-6 and CCL2 in Adipocytes Treated with Small Interfering RNA (siRNA) for RAGE

In order to see the mechanism of HMGB1- and AGE-induced gene expression of IL-6 and CCL2, RAGE gene was knocked down by RNA interference. The expression of IL-6 and CCL2 was significantly increased by the addition of HMGB1 and AGE even in the presence of scrambled RNA. In contrast, introduction of small interfering RNA (siRNA) for RAGE (siRAGE) clearly inhibited the HMGB1- and AGE-induced increases of mRNAs for IL- 6 and CCL2 in SW872 human adipocytes (Figure 4; $P=0.2638$ [No addition vs. HMGB1 in IL-6], $P=0.0744$ [No addition vs. AGE in IL-6], $P=0.2559$ [No addition vs. HMGB1 in CCL2], and $P=0.5541$ [No addition vs. AGE in CCL2]).

We also measured the concentrations of IL- 6 and CCL2 in the RAGE-knocked-down SW872 cell culture medium via enzyme-linked immunosorbent assay (ELISA). The concentrations of IL- 6 and CCL2 were significantly increased in response to HMGB1 and AGE in scrambled RNA-introduced cell culture medium. In contrast, the introduction of siRAGE significantly attenuated the HMGB1- and AGE-induced increases of IL-6 and CCL2 in the medium (Figure 5).

\subsection{Up-Regulation of IL-6 and CCL2 by Lipopolysaccharide (LPS) in Adipocytes}

Recent reports indicated that PE/HDP is also induced by lipopolysaccharide (LPS) [32] and that RAGE mediates LPS signaling and acts as an LPS receptor [33-38]. Thus, we tested whether LPS up-regulate gene expression of $I L-6$ and CCL2 in human SW872 adipocytes. We added $10 \mathrm{ng} / \mathrm{mL}$ LPS in SW872 culture medium, incubated for $24 \mathrm{~h}$, and the expression of $I L-6$ and CCL2 was analyzed via 
real-time RT-PCR. As shown in Figure 6, mRNAs of IL-6 and CCL2 were significantly up-regulated by the addition of LPS.
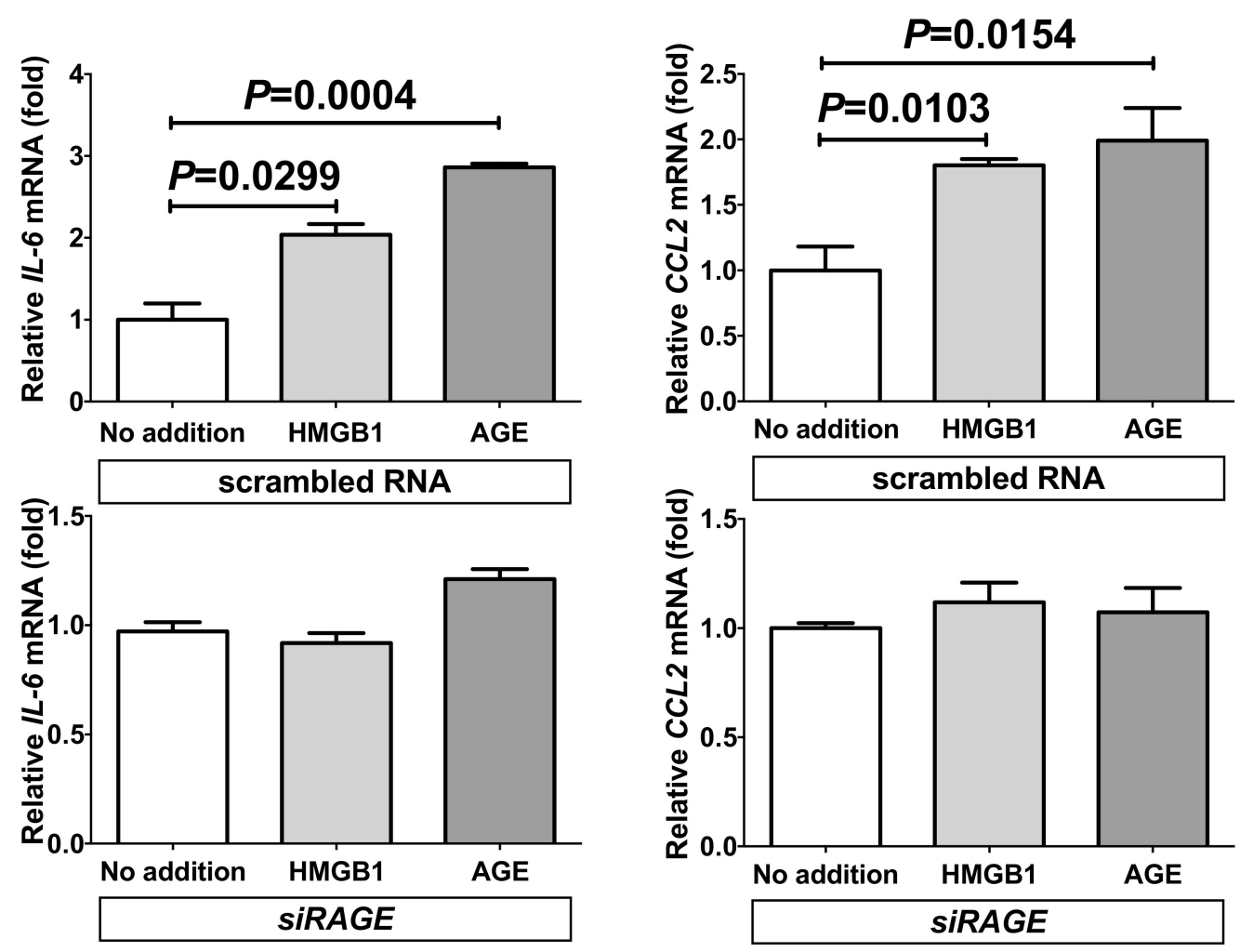

Figure 4. Effects of siRNA against RAGE on HMGB1- and AGE-induced gene expression of IL-6 and CCL2. SiRNA for RAGE was transfected into SW872 cells and the cells were incubated with HMGB1 or AGE for $24 \mathrm{~h}$. The levels of IL-6 and CCL2 mRNA were measured via real-time RT-PCR using $\beta$-actin as an endogenous control. Data are expressed as mean \pm SE for each group $(n=4)$. The statistical analyses were performed using Student's $t$-test vs. No addition.
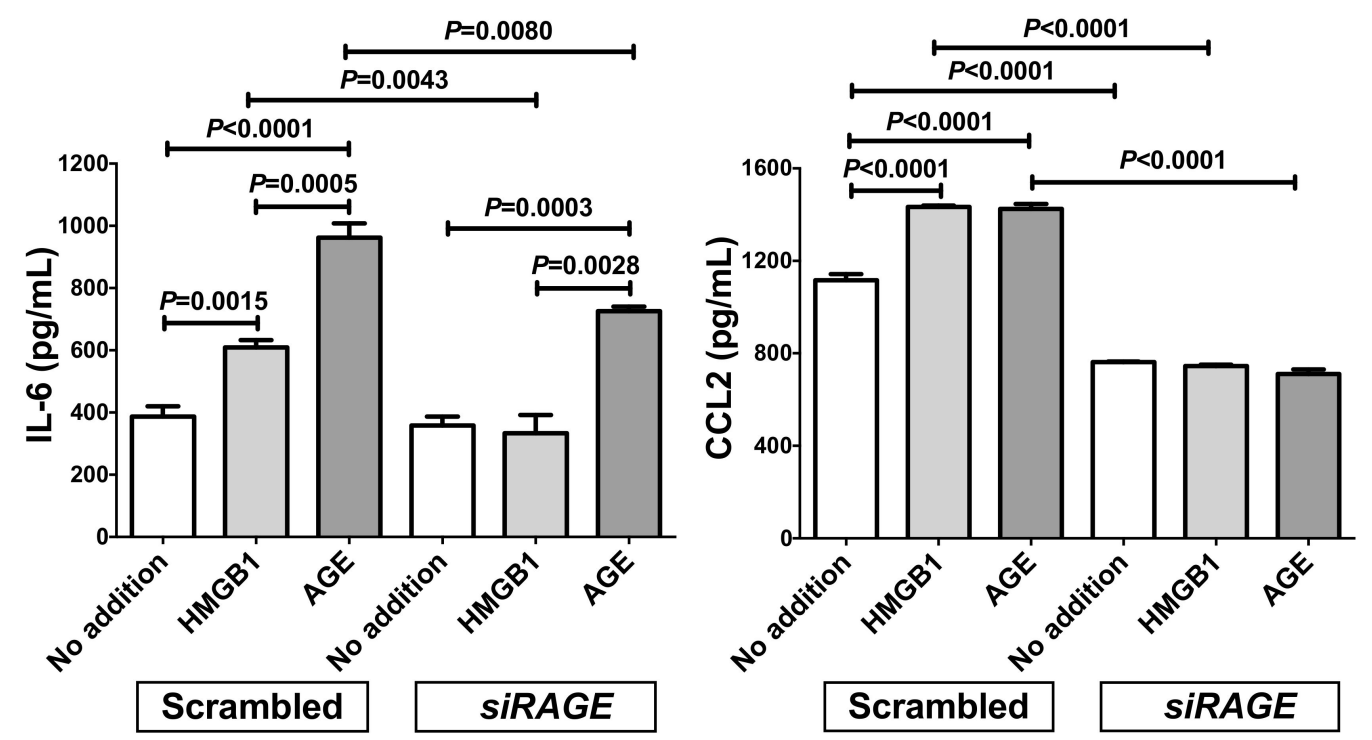

Figure 5. Effect of siRNA against RAGE on the HMGB1- and AGE-induced expression of IL-6 and CCL2. SiRNA for RAGE was transfected into SW872 cells and the cells were incubated with HMGB1 or AGE for $24 \mathrm{~h}$. The levels of IL-6 and CCL2 in the cell culture medium were measured via ELISA. Data are expressed as mean \pm SE for each group $(n=4)$. The statistical analyses were performed using Student's $t$-test vs. No addition. 

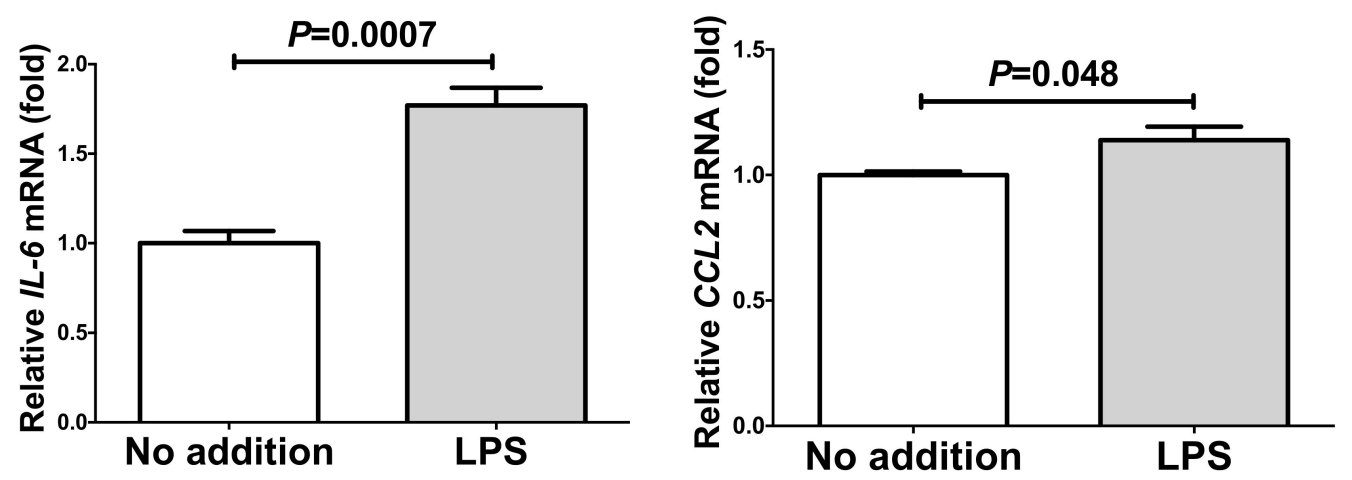

Figure 6. The mRNA levels of IL-6 and CCL2 in SW872 human adipocytes treated with $10 \mathrm{ng} / \mathrm{mL}$ lipopolysaccharide (LPS) for $24 \mathrm{~h}$. The levels of the mRNAs were measured via real-time RT-PCR using $\beta$-actin as an endogenous control. Data are expressed as mean \pm SE for each group $(n=4)$. The statistical analyses were performed using Student's $t$-test.

We next measured IL-6 and CCL2 in the LPS-stimulated SW872 cell culture medium and found that the levels of IL- 6 and CCL2 in the LPS-stimulated SW872 culture medium were also elevated significantly (Figure 7).
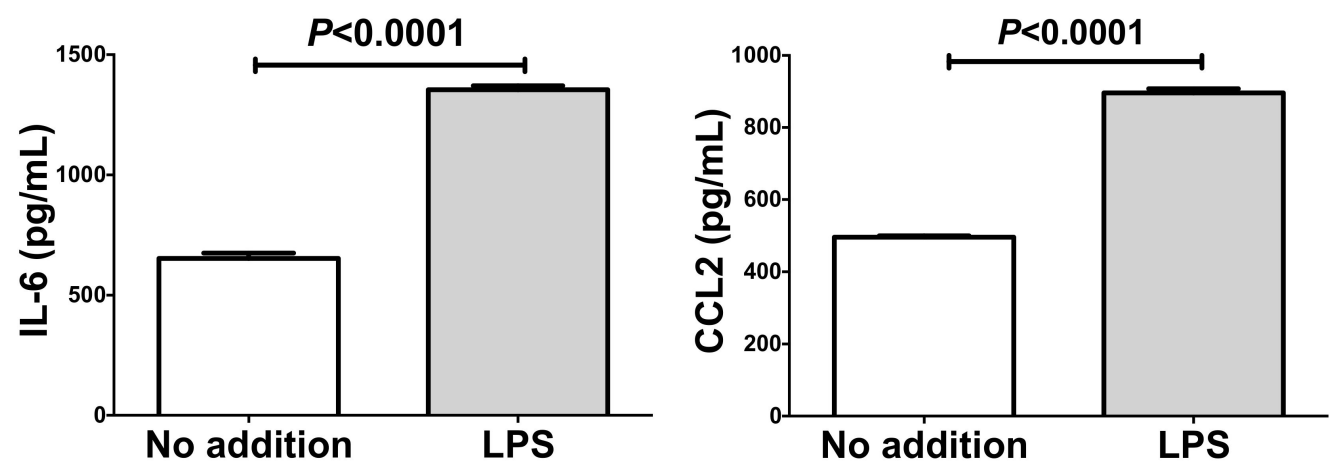

Figure 7. The levels of IL-6 and CCL2 in culture medium of SW872 human adipocytes treated with $10 \mathrm{ng} / \mathrm{mL}$ LPS for $24 \mathrm{~h}$. The levels of IL-6 and CCL2 in the cell culture medium were measured via ELISA. Data are expressed as mean \pm SE for each group $(n=4)$. The statistical analyses were performed using Student's $t$-test.

\subsection{Down-Regulation of RAGE Attenuated the LPS-Induced IL-6 and CCL2 Increases in Adipocytes}

In order to confirm whether the mechanism of LPS-induced IL-6 and CCL2 up-regulation is also mediated by RAGE, RAGE gene was knocked down by RNA interference. The expression of IL- 6 and CCL2 was significantly increased by the addition of LPS even in the presence of scrambled RNA. In contrast, introduction of $s i R A G E$ clearly inhibited the LPS-induced increases of mRNAs for IL-6 and CCL2 in SW872 human adipocytes (Figure 8).

We also measured the concentrations of IL-6 and CCL2 in the RAGE-knocked-down SW872 cell culture medium via ELISA. The concentrations of IL-6 and CCL2 were significantly increased in response to the addition of LPS in scrambled RNA-introduced cell culture medium. In contrast, the introduction of siRAGE significantly attenuated the LPS-induced increases of IL-6 and CCL2 in the medium (Figure 9). 

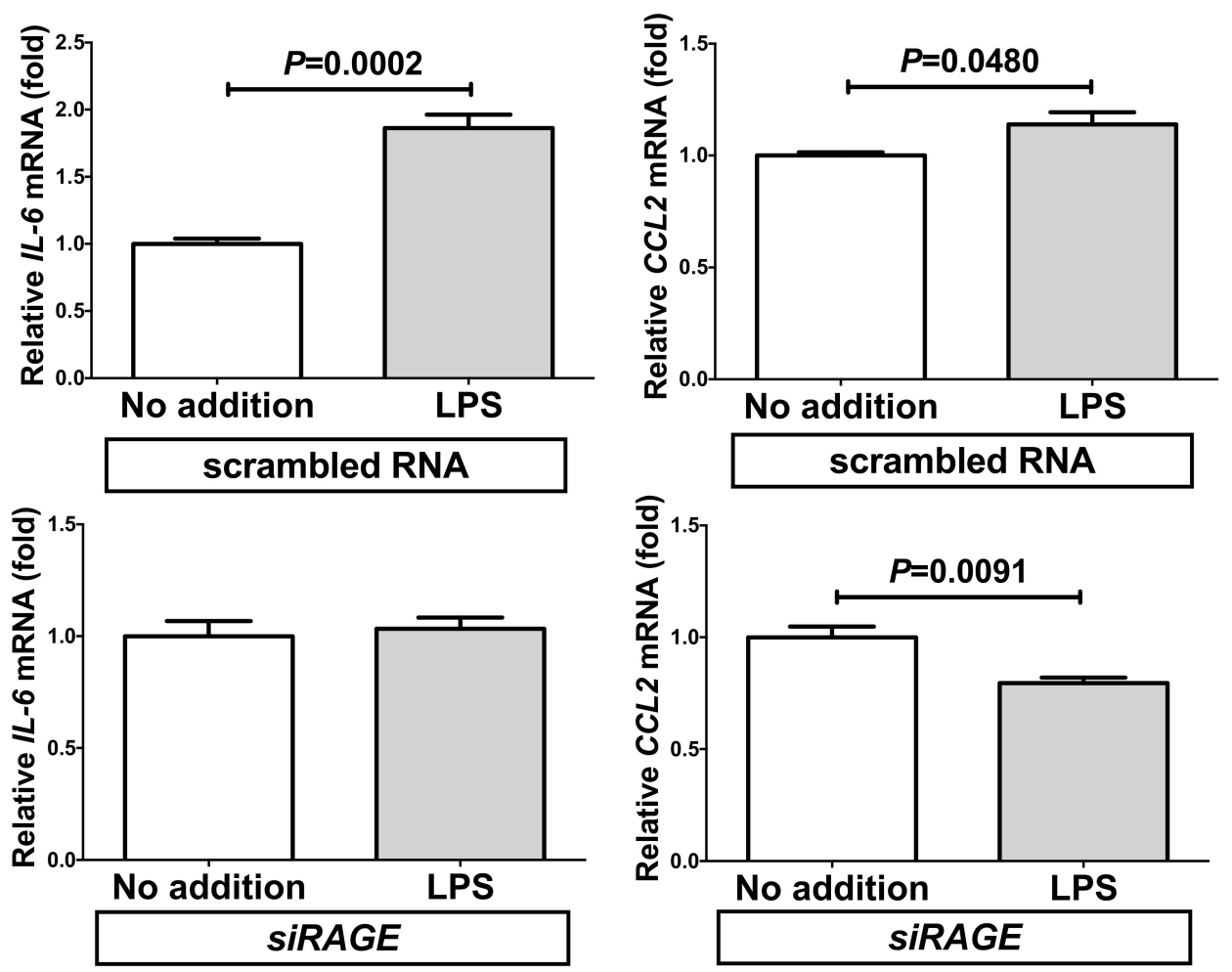

Figure 8. Effects of siRNA against RAGE on the LPS-induced gene expression of $I L-6$ and CCL2. SiRNA for RAGE was transfected into SW872 cells and the cells were incubated with $10 \mathrm{ng} / \mathrm{mL}$ LPS for $24 \mathrm{~h}$. The levels of $I L-6$ and CCL2 mRNA were measured via real-time RT-PCR using $\beta$-actin as an endogenous control. Data are expressed as mean $\pm \mathrm{SE}$ for each group $(n=4)$. The statistical analyses were performed using Student's $t$-test.
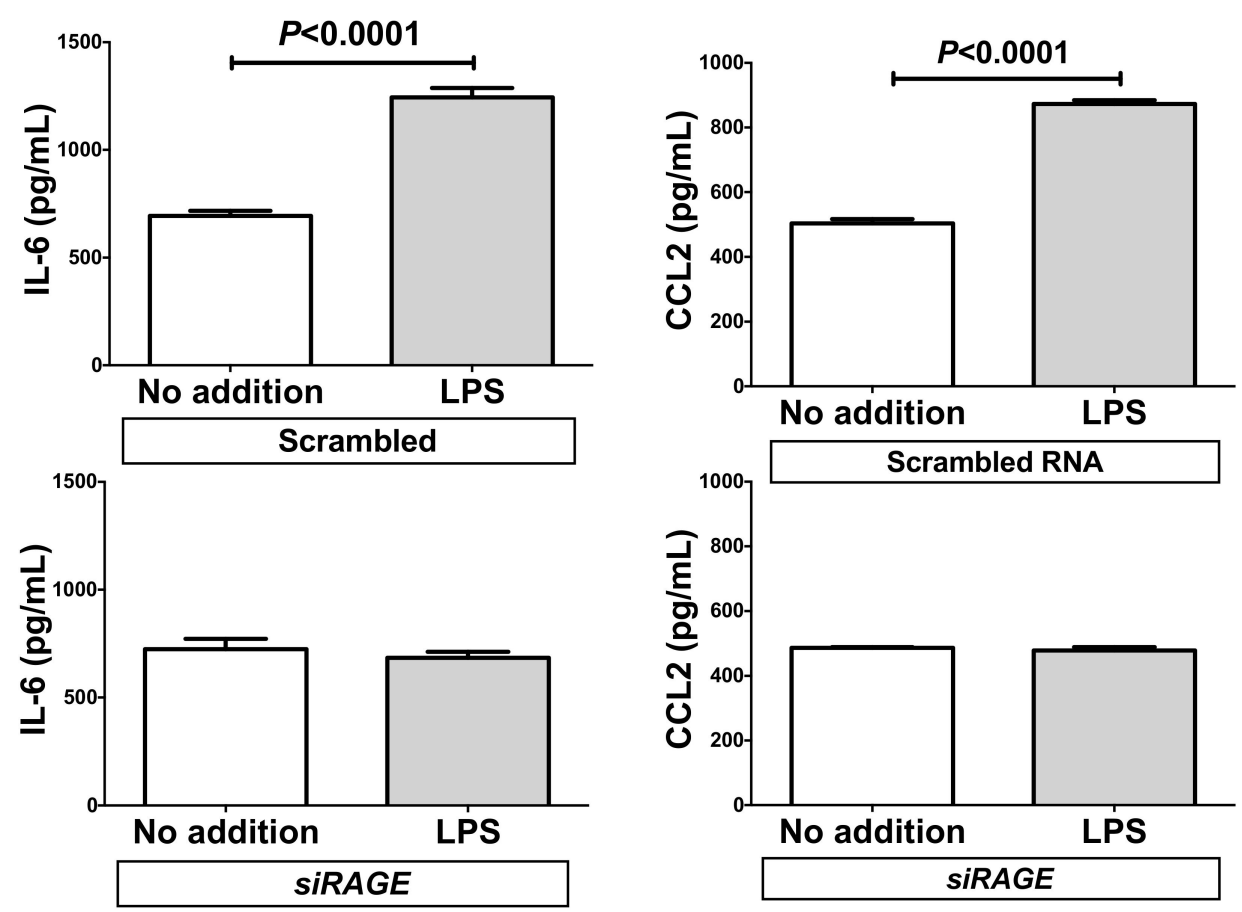

Figure 9. Effect of siRNA against RAGE on the LPS-induced expression of IL-6 and CCL2. SiRNA for RAGE was transfected into SW872 cells and the cells were incubated with LPS for $24 \mathrm{~h}$. The levels of IL- 6 and CCL2 in the cell culture medium were measured via ELISA. Data are expressed as mean \pm SE for each group $(n=4)$. The statistical analyses were performed using Student's $t$-test. 


\section{Discussion}

Previous studies indicated that body mass index (BMI), anemia, lower education, maternal age, primiparity, multiple pregnancy, PE/HDP in previous pregnancy, gestational diabetes mellitus, preexisting hypertension, preexisting type 2 diabetes mellitus, preexisting urinary tract infection, and a family history of hypertension, type 2 diabetes mellitus, or PE/HDP are potential risk factors for PE/HDP $[39,40]$. Of the risk factors, obesity is a major risk factor and is associated with an increased risk for obstetrical complications such as gestational diabetes mellitus, PE/HDP, pre-term delivery, and Cesarean section [41-45], and increased neonatal morbidity and mortality [42,46,47]. Maternal obesity has been associated with low-grade metabolic inflammation due to increased release of adipokines, which are believed to contribute to maternal glucose intolerance and insulin resistance and cardiovascular and neuroendocrine modulation associated with increased maternal BMI [48]. Increased cytokine and decreased adiponectin release from adipose tissue have been linked to the meta-inflammatory state of obesity [49,50].

In this study, we measured the mRNA levels for adipokines (LEP, ADIP, and RETN) in human primary adipocytes and found that they were not up-regulated in response to the addition of sera from PE/HDP patients. We also measured mRNA levels of $T N F \alpha, I L-6$, and CCL2, which have been reported to play important roles in pathogenesis or development of PE/HDP, and found that the expression of IL-6 and CCL2 was elevated in response to the addition of PE/HDP sera. In addition, the mRNA levels of RAGE system members (HMGB1, S100B, and RAGE) were significantly elevated by the addition of PE/HDP patient sera, suggesting possible involvement of the RAGE system in the up-regulation of $I L-6$ and CCL2 in adipocytes. In order to verify this possibility, we tested whether RAGE ligands up-regulate expression of IL-6 and CCL2 using human SW872 adipocytes and mouse 3T3-L1 cells and found that AGE and HMGB1 but not S100B significantly up-regulated gene expression of IL- 6 and CCL2 in SW872 cells. In contrast to SW872 cells, AGE and HMGB1 up-regulated the gene expression of IL-6 in differentiated 3T3-L1 cells but not in undifferentiated cells, and the addition of AGE, but neither HMGB1 nor S100B, up-regulated Ccl2 expression in undifferentiated 3T3-L1 cells but any of them up-regulated $\mathrm{C} c l 2$ in differentiated cells. These results indicate that RAGE ligands, especially AGE and HMGB1, stimulate adipocytes to induce gene expression of IL-6 and CCL2.

IL-6 is a key player in tissue inflammation and insulin resistance, and was observed in higher serum concentrations in PE/HDP patients [51]. CCL2, also referred as monocyte chemoattractant protein-1, is a key regulator of monocyte infiltration of adipose tissue, and it plays a central role in the development and maintenance of chronic adipose tissue inflammation and insulin resistance $[23,52,53]$. Therefore, IL- 6 and CCL2 could be key players produced from adipocytes to induce tissue damages in PE/HDP patients.

Exposure of the amino acid residues of proteins to reducing sugars, such as glucose, results in non-enzymatic glycation, which forms reversible Schiff bases and subsequently Amadori compounds. A series of further complex molecular rearrangements including dehydration, condensation, and crosslinking, yield irreversible and heterogeneous derivatives termed AGE. AGEs are chemically heterogeneous groups of compounds. Apart from endogenously formed AGEs, exogenous AGEs from foods are absorbed in the gastrointestinal tract and reportedly constitute $\sim 10 \%$ of total AGE in the body. In animal studies, the restriction of dietary AGE intake significantly improved insulin sensitivity and extended lifespan.

HMGB1 is a nuclear protein that stabilizes nucleosome formation and facilitates transcription. HMGB1 is a strong inflammatory trigger from necrotic cells as a result of passive leakage, and can be actively secreted by activated monocytes, macrophages, dendritic cells, natural killer cells, and endothelial cells, though there is no canonical signal sequence in the HMGB1 protein. It is well-known that the levels of AGE in serum such as hemoglobin $\mathrm{A} 1 \mathrm{c}(\mathrm{HbA1c})$ are increased in diabetes (hyperglycemia) patients and that diabetes is a typical risk factor for PE/HDP. Elevated HMGB1 was observed in pregnant women with other pro-inflammatory conditions as obesity and pre-term labor. It is well established that labor is associated with a pro-inflammatory systemic response. Extracellular 
HMGB1 exerts its cytokine-like activity by binding to RAGE receptor. In fact, the serum HMGB1 levels were significantly increased in the PE/HDP patients $(329.2 \pm 93.18 \mathrm{ng} / \mathrm{mL})$ than those in control patients $(35.45 \pm 25.11 \mathrm{ng} / \mathrm{mL})(P=0.0473)$. In the management of pregnant women, monitoring of blood glucose and $\mathrm{HbA} 1 \mathrm{c}$ are very common but HMGB1 levels in serum are rarely monitored. Although the numbers of PE/HDP patients in our study were relatively small, the increased tendency of serum HMGB1 in PE/HDP patients suggests that the serum HMGB1 measuring could be a new marker for screening of PE/HDP risk.

As AGE and HMGB1 are ligands for RAGE, it is quite possible that AGE- and HMGB1-induced up-regulation of $I L-6$ and $C C L 2$ is mediated via RAGE. In fact, the introduction of siRAGE abolished the AGE- and HMGB1-mediated increases of gene expression of IL- 6 and CCL2 in adipocytes (Figures 4 and 5), indicating involvement of AGE and/or HMGB1/RAGE system in the up-regulation of IL-6 and CCL2 in adipocytes. Among major RAGE ligands, we tested S100B, in addition to AGE and HMGB1, but S100B failed to increase gene expression of IL-6 and CCL2. As most but not all the ligands for RAGE up-regulate (pro)inflammatory mediators, such as IL-6 and CCL2, some other RAGE ligands such as macrophage-1 antigen/cluster of differentiation molecule 11b [54], amyloid $\beta$ peptide [55], $\beta$-sheet fibrils [56], advanced oxidation protein products [57], complement C3a [58], LPS [33], and phosphatidylserine on the surface of apoptotic cells [59] might increase the expression of IL-6 and CCL2, leading to PE/HDP in pregnant women. In fact, recent reports showed that PE/HDP was also induced by LPS [32], and that RAGE mediated LPS signaling and acted as an LPS receptor [33-38]. Thus, we tested whether LPS up-regulate gene expression of IL-6 and CCL2 in human SW872 adipocytes, and found that LPS significantly up-regulated the expression of IL-6 and CCL2 in SW872 cells via RAGE (Figures 6-9).

Some soluble products of RAGE such as soluble RAGE (sRAGE) and endogenous secretory RAGE (esRAGE) are generated from RAGE gene and modulate the RAGE signaling [60,61]. It was previously reported that the levels of sRAGE were reduced in PE/HDP patient serum and that serum esRAGE and the esRAGE/sRAGE ratio were elevated in PE/HDP patient serum [62]. It was also reported that pregnancy induced a significant increase in RAGE protein levels in both myometrium and omental vasculature and that blood vessels from women with preeclampsia had intense staining for RAGE in both vessel beds [63]. In the present study, we showed the up-regulation of RAGE in adipocytes by PE/HDP sera (Figure 1) but did not see sRAGE and esRAGE. Reduction of sRAGE and elevation of esRAGE/sRAGE ratio could be a potential marker for screening of PE/HDP risk.

Nuclear factor $\kappa$-light-chain-enhncer of activated B cells $(\mathrm{NF}-\mathrm{kB})$ is a key transcription factor for the expression of IL-6 and CCL2 [64,65]. RAGE ligands usually activate NF- $\mathrm{KB}$ [66]. The RAGE-NF-kB-IL-6/CCL2 pathway might function in adipocytes stimulated by RAGE ligands (AGE, HMGB1, and LPS), resulting in the development of inflammation that may lead to PE/HDP in pregnant women.

\section{Materials and Methods}

\subsection{Patient Samples}

The study was approved by the Local Ethics Committee at Nara Medical University (Kashihara, Japan; approval number 873, 24 July 2014), and all participants provided written informed consent. We included PE/HDP patients with a pregnancy and disease-free pregnant women with pregnancy were the control (Table 1). The participants' BMI values before pregnancy were less than $25 \mathrm{~kg} / \mathrm{m}^{2}$ with gestational age-matched normal pregnant women at 27 weeks' gestation or later. All subjects were Eastern Asian origin, and none of the subjects were taking any medication or showed evidence of any metabolic diseases or other complications besides PE/HDP. PE/HDP was defined as new onset and diagnosed based on two consecutive measurements of diastolic and systolic blood pressure, diastolic blood pressure greater than or equal to $90 \mathrm{mmHg}$, or systolic blood pressure was greater than or equal to $140 \mathrm{mmHg}$, with urine protein over $300 \mathrm{mg} /$ day, occurring diagnosed after 20 weeks of 
gestation [67]. All subjects (4 patients and 4 controls) provided serum samples for analysis and did not have gestational diabetes mellitus, thyroid malfunction, or other complications. All venous blood samples were obtained after an overnight fast at routine medical examination. The sera were separated immediately and stored at $-80{ }^{\circ} \mathrm{C}$ for 3 years at the longest and 6 months at the shortest. HMGB1 concentrations of the sera were measured using Human HMGB1 ELISA kit (Arigo Biolaboratories Corp., Hsinchu, Taiwan).

Table 1. Clinical characteristics of patients/controls involved in the study.

\begin{tabular}{lllll}
\hline Patients/Controls & Age (Years) & BMI & Gestational Age at Blood Sampling (Week) & Parity \\
\hline PE/HDP \#1 & 33 & 23.2 & 30 & 0 \\
PE/HDP \#2 & 27 & 21.9 & 29 & 1 \\
PE/HDP \#3 & 28 & 21.3 & 28 & 0 \\
PE/HDP \#4 & 29 & 23.4 & 27 & 0 \\
Control \#1 & 30 & 22.4 & 28 & 0 \\
Control \#2 & 29 & 24.6 & 28 & 0 \\
Control \#3 & 26 & 23.8 & 27 & 0 \\
Control \#4 & 33 & 22.4 & 28 & 2 \\
\hline
\end{tabular}

\subsection{Cell Culture and Treatment}

Human primary visceral preadipocytes were purchased from ZenBio, Inc. (Research Triangle Park, NC, USA). The cells were differentiated to adipocytes according to the supplier's protocol, and their differentiation to mature adipocyte was confirmed by Oil Red O staining. The primary adipocytes were incubated with 10\% individual PE/HDP patient serum (\#1 \#4) and control serum (\#1 \#4) for $24 \mathrm{~h}$. Human SW872 adipocytes were purchased from American Type Culture Collection (ATCC, Manassas, VA), and cultured at $37^{\circ} \mathrm{C}$ with $5 \% \mathrm{CO}_{2}$ in DMEM medium (Wako Pure Chemical Industries, Ltd., Osaka, Japan) supplemented with $10 \%$ fetal calf serum (FCS), 100 units/mL penicillin G (Wako) and $100 \mu \mathrm{g} / \mathrm{mL}$ streptomycin (Wako) as described [68]. Mouse 3T3-L1 preadipocytes were purchased from Japanese Collection of Research Bioresources (JCRB) Cell Bank (Ibaraki, Japan), and cell culture and differentiation of 3T3-Ll preadipocytes were performed as described by Ntambi et al. [69,70]. Briefly, confluent 3T3-Ll pre-adipocytes monolayers were incubated for $72 \mathrm{~h}$ in DMEM medium containing 10\% FCS, $0.5 \mathrm{mM}$ methylisobutylxanthine (IBMX; Wako), $1 \mu \mathrm{M}$ dexamethasone (Wako), and $10 \mu \mathrm{g} / \mathrm{mL}$ insulin (Wako). After $72 \mathrm{~h}$ the cells were washed free of IBMX and dexamethasone and maintained in DMEM medium containing 10\% FCS and $10 \mu \mathrm{g} / \mathrm{mL}$ insulin for $72 \mathrm{~h}$. Adipocyte morphology was monitored by the appearance of cytoplasmic triacylglycerol droplets, which is closely correlated with the acquisition of the adipocyte phenotype. For the stimulation experiments, SW872 and 3T3-L1 cells (undifferentiated preadipocytes and differentiated adipocytes) were treated with $150 \mu \mathrm{g} / \mathrm{mL}$ (for SW872) or $300 \mu \mathrm{g} / \mathrm{mL}$ (for 3T3-L1) AGE-bovine serum albumin (BSA) (Calbiochem ${ }^{\circledR}$, Merck KGaA, Darmstadt, Germany), 1 kg/mL HMGB1 (Bio-Techne, Minneapolis, MN) or $100 \mathrm{ng} / \mathrm{mL}$ S100B (Medical \& Biological Laboratories Co., Ltd., Nagoya, Japan). SW872 cells were also treated with $10 \mathrm{ng} / \mathrm{mL}$ E. coli LPS (Wako) for $24 \mathrm{~h}$ as described [33].

\subsection{Real-Time Reverse Transcriptase-Polymerase Chain Reaction (RT-PCR)}

Total RNA was isolated using a RNeasy Protect Cell Mini Kit (Qiagen, Hilden, Germany) from primary cultured human visceral adipocytes, SW872, and 3T3-L1 adipocytes/preadipocytes, and cDNA was synthesized from total RNA as template using a High Capacity cDNA Reverse Transcription kit (Applied Biosystems, Foster City, CA) as described [68,70-82]. Real-time polymerase chain reaction (PCR) was performed using SYBR ${ }^{\circledR}$ Fast qPCR kit (KAPA Biosystems, Boston, MA) and a Thermal Cycler Dice Real Time System (Takara Bio Inc., Kusatsu, Japan). All the PCR primers were synthesized by Nihon Gene Research Laboratories, Inc. (NGRL; Sendai, Japan), and the primer sequences for each primer set are described in Table 2. PCR was performed with an initial step of $3 \mathrm{~min}$ at $95^{\circ} \mathrm{C}$ 
followed by 40 cycles of $3 \mathrm{~s}$ at $95^{\circ} \mathrm{C}$ and $20 \mathrm{~s}$ at $60^{\circ} \mathrm{C}$ for human $\beta$-actin, mouse rat insulinoma gene (Rig)/ribosomal protein S15 (RpS15), mouse IL-6, human and mouse CCL2, human LEP, human ADIP, human RETN, human S100B, human HMGB1, and human RAGE, and with an initial step of 3 min at $95{ }^{\circ} \mathrm{C}$ followed by 40 cycles of $3 \mathrm{~s}$ at $95^{\circ} \mathrm{C}$ and $20 \mathrm{~s}$ at $62{ }^{\circ} \mathrm{C}$ for human IL- 6 and human TNF $\alpha$. The mRNA expression levels were normalized to the mRNA level of Rig/RpS15 in mouse samples or $\beta$-actin in human samples [68,70-85].

Table 2. Primers used for real-time reverse transcriptase-polymerase chain reaction (RT-PCR).

\begin{tabular}{|c|c|}
\hline Target mRNA & Primer Sequence (Position) \\
\hline \multirow{2}{*}{ Human IL-6 (NM_000600) } & 5'-GGTACATCCTCGACGGCATC-3' (289-308) \\
\hline & $5^{\prime}$ - GCCTCTTTGCTGCTTTCACAC-3' (347-367) \\
\hline \multirow{2}{*}{ Human CCL2 (NM_002982) } & 5'-GTCTCTGCCGCCCTTCTGT-3' (80-98) \\
\hline & 5'-TTGCATCTGGCTGAGCGAG-3' (137-155) \\
\hline \multirow{2}{*}{ Human TNF $\alpha$ (NM_000594) } & 5'-CTTCTCCTTCCTGATCGTGG-3' (280-299) \\
\hline & 5'-TCTCAGCTCCACGCCATT-3' (518-535) \\
\hline \multirow{2}{*}{ Human LEP (NM_000230) } & 5'-GGCTTTGGCCCTATCTTTTC-3' (89-108) \\
\hline & 5'-GGATAAGGTCAGGATGGGGT-3' (257-276) \\
\hline \multirow{2}{*}{ Human ADIP (NM_001177800) } & 5'-CATGACCAGGAAACCACGACT-3' (181-201) \\
\hline & 5'-TGAATGCTGAGCGGTAT-3' (465-481) \\
\hline \multirow{2}{*}{ Human RETN (NM_020415) } & 5'-TCСТCСТССТСССТGTCCTGG-3' (63-83) \\
\hline & 5'-CAGTGACATGTGGTCTGGGCG-3' (298-318) \\
\hline \multirow{2}{*}{ Human S100B (NM_006272) } & 5'-AGGGAGGGAGACAAGCACAA-3' (172-191) \\
\hline & 5'-ACTCGTGGCAGGCAGTAGTA-3' (293-312) \\
\hline \multirow{2}{*}{ Human HMGB1 (NM_001313893) } & 5'-ATATGGCAAAAGCGGACAAG-3' (1126-1145) \\
\hline & 5'-AGGCCAGGATGTTCTCCTTT-3' (1281-1300) \\
\hline \multirow{2}{*}{ Human RAGE (NM_001136) } & 5'-TGGAACCGTAACCCTGACCT-3' (856-875) \\
\hline & 5'-CGATGATGCTGATGCTGACA-3' (1045-1064) \\
\hline \multirow{2}{*}{ Human $\beta$-actin (NM_001101) } & 5'-GCGAGAAGATGACCCAGA-3' (420-437) \\
\hline & 5'-CAGAGGCGTACAGGGATA-3' (492-509' \\
\hline \multirow{2}{*}{ Mouse IL-6 (NM_031168) } & 5'-GTATGAACAACGATGATGCACTTG-3' (305-328) \\
\hline & 5'-ATGGTACTCCAGAAGACCAGAGGA-3' (418-441) \\
\hline \multirow{2}{*}{ Mouse Ccl2 (NM_011333) } & 5'-CСАСТCACСТGCTGCTACTCAT-3' (176-197) \\
\hline & 5'-TGGTGATCCTCTTGTAGCTCTCC-3' (229-251) \\
\hline \multirow{2}{*}{ Mouse Rig/RpS15 (NM_009091) } & 5'-ACGGCAAGACCTTCAACCAG-3' (323-342) \\
\hline & 5'-ATGGAGAACTCGCCCAGGTAG-3' (372-392) \\
\hline
\end{tabular}

\subsection{Measurement of IL-6 and CCL2 Concentrations in Culture Medium via ELISA}

Cells were stimulated with HMGB1 $(1 \mu \mathrm{g} / \mathrm{mL})$, AGE (150 and $300 \mu \mathrm{g} / \mathrm{mL})$, S100B $(100 \mathrm{ng} / \mathrm{mL})$, and LPS $(10 \mathrm{ng} / \mathrm{mL})$ for $24 \mathrm{~h}$, culture medium was collected, and the concentrations of IL-6 and CCL2 were measured by using a Human IL-6 ELISA kit (RayBiotech, Norcross, GA, USA) for IL-6 and a Quantikine ${ }^{\circledR}$ ELISA Human CCL2/MCP-1 Immunoassay kit (R\&D Systems, Inc., Minneapolis, MN, USA) for CCL2, according to the instructions of suppliers.

\subsection{RNA Interference (RNAi)}

Small interfering RNA (siRNA) directed against human RAGE was synthesized by NGRL. The sense sequence of siRNA for human RAGE was 5'-AUCUACAAUUUCUGGCUUCtt-3' (corresponding to 466-484 of NM_001136) as described [76,78]. The Silencer ${ }^{\circledR}$ Select human scrambled siRNA was purchased from Ambion ${ }^{\circledR}$ (Waltham, MA, USA) and used as a control. Transfection of siRNAs to SW872 cells was carried out using Lipofectamine ${ }^{\circledR}$ RNAiMAX Reagent (Life Technologies, Waltham, MA, USA) as described [68,72,74-80]. Cells were transfected with 5 pmol siRNA per 24-well culture dish $\left(4.0 \times 10^{5}\right.$ cells $/ \mathrm{mL}$ in 24 -well plates). 


\subsection{Data Analysis}

Results are expressed as mean \pm SE. The data obtained were checked against Shapiro-Wilk normality test, which found that all the $P$ values were larger than 0.05 , and the statistical significance was determined by Student's $t$-test using GraphPad Prism ver. 6.0 for Mac OSX software (GraphPad Software, La Jolla, CA, USA).

Author Contributions: J.A., K.N., T.S., S.T., and H.K. contributed to the study design. J.A., T.U., M.M., A.Y., H.O., S.S.-T., A.I.-H., and S.T. contributed to data collection. J.A., S.T., and H.K. contributed to data analysis. J.A., S.T., and H.K. contributed to data interpretation. J.A., S.T., and H.K. contributed to manuscript preparation. All the authors contributed to revising and approval of manuscript content.

Funding: This research was funded by JSPS KAKEN Grants JP15K10682 and JP19K09829.

Acknowledgments: This work was supported in part by Grants-in-Aid for Scientific Research from the Ministry of Education, Culture, Sports, Science and Technology (JSPS: 23659161), Japan, JSPS KAKEN Grants JP15K10682 and JP19K09829, and the Japan Science and Technology Agency (JST: 18•06255) and is partial fulfillment by Juria Akasaka of the degree of Doctor of Medical Science at Nara Medical University.

Conflicts of Interest: The authors declare no conflict of interest.

\section{Abbreviations}

$\begin{array}{ll}\text { ADIP } & \text { Adiponectin } \\ \text { AGE } & \text { Advanced glycation endproduct(s) } \\ \text { BMI } & \text { Body mass index } \\ \text { CCL2 } & \text { C-C motif chemokine ligand 2 } \\ \text { ELISA } & \text { Enzyme-linked immunosorbent assay } \\ \text { esRAGE } & \text { Endogenous secretory RAGE } \\ \text { FCS } & \text { Fetal calf serum } \\ \text { HbA1c } & \text { Hemoglobin A1c } \\ \text { HMGB1 } & \text { High mobility group box 1 } \\ \text { IBMX } & \text { Methylisobutylxanthine } \\ \text { IL-6 } & \text { Interleukin-6 } \\ \text { LEP } & \text { Leptin } \\ \text { LPS } & \text { Lipopolysaccharide } \\ \text { NF-KB } & \text { Nuclear factor k-light-chain-enhancer of activated B cells } \\ \text { PCR } & \text { Polymerase chain reaction } \\ \text { PE/HDP } & \text { Preeclampsia/hypertensive disorders of pregnancy } \\ \text { RAGE } & \text { Receptor for advanced glycation endproduct(s) } \\ \text { RETN } & \text { Resistin } \\ \text { Rig/RpS15 } & \text { Rat insulinoma gene/Ribosomal protein S15 } \\ \text { RT-PCR } & \text { Reverse transcriptase-PCR } \\ \text { S100B } & \text { S100 Ca }{ }^{2+} \text {-binding protein B } \\ \text { siRNA } & \text { Small interfering RNA } \\ \text { sRAGE } & \text { Soluble RAGE } \\ \text { TNF } \alpha & \text { Tumor necrosis factor } \alpha\end{array}$

\section{References}

1. Walker, J.J. Pre-eclampsia. Lancet 2000, 356, 1260-1265. [CrossRef]

2. Kintiraki, E.; Papakatsika, S.; Kotronis, G.; Goulis, D.G.; Kotsis, V. Pregnancy-induced hypertension. Hormones 2015, 14, 211-223. [CrossRef] [PubMed]

3. Goldenberg, R.L.; Culhane, J.F.; Iams, J.D.; Romero, R. Epidemiology and causes of preterm birth. Lancet 2008, 371, 75-84. [CrossRef]

4. Freeman, D.J.; McManus, F.; Brown, E.A.; Cherry, L.; Norrie, J.; Ramsay, J.E.; Clark, P.; Walker, I.D.; Sattar, N.; Greer, I.A. Short- and long-term changes in plasma inflammatory markers associated with preeclampsia. Hypertension 2004, 44, 708-714. [CrossRef] [PubMed] 
5. Von Versen-Hoeynck, F.M.; Powers, R.W. Maternal-fetal metabolism in normal pregnancy and preeclampsia. Front. Biosci. 2007, 12, 2457-2470. [CrossRef] [PubMed]

6. Boeldt, D.S.; Bird, I.M. Vascular adaptation in pregnancy and endothelial dysfunction in preeclamsia. J. Endocrinol. 2017, 232, R27-R44. [CrossRef]

7. Possomato-Vieira, J.S.; Khalil, R.A. Mechanisms of endothelial dysfunction in hypertensive pregnancy and preeclampsia. Adv. Pharmacol. 2016, 77, 361-431.

8. Brennan, L.J.; Morton, J.S.; Davidge, S.T. Vascular dysfunction in preeclampsia. Microcirculation 2014, 21, 4-14. [CrossRef]

9. Yang, X.; Guo, L.; Li, H.; Chen, X.; Tong, X. Analysis of the original causes of placental oxidative stress in normal pregnancy and preeclampsia: a hypothesis. J. Matem. Fetal Neonatal Med. 2012, 25, 884-888. [CrossRef]

10. Fisher, S.J. Why is placentation abnormal in preeclampsia? Am. J. Obstet. Gynecol. 2015, 213, S115-S122. [CrossRef]

11. Saito, S.; Nakashima, A. A review of the mechanism for poor placentation in early-onset preeclampsia: the role of autophagy in trophoblast invasion vascular remodeling. J. Reprod. Immunol. 2014, 101, 80-88. [CrossRef] [PubMed]

12. Harmon, A.C.; Cornelius, D.C.; Amaral, L.M.; Faulkner, J.L.; Cunningham, W.W., Jr.; Wallace, K.; LaMarca, B. The role of inflammation in the pathology of preeclampsia. Clin. Sci. 2016, 130, 409-419. [CrossRef] [PubMed]

13. Kalagiri, R.R.; Carder, T.; Choudhury, S.; Vora, N.; Ballard, A.R.; Govande, V.; Drever, N.; Beeram, M.R.; Uddin, M.N. Inflammation in complicated pregnancy and its outcome. Am. J. Perinatol. 2016, 33, 1337-1356. [CrossRef] [PubMed]

14. Shamshirsaz, A.A.; Paidas, M.; Krikun, G. Preeclamsia, hypoxia, thrombosis, and inflammation. J. Pregnancy 2012, 2012, 374047. [CrossRef]

15. Kim, Y.J. Pathogenesis and promising non-invasive markers for preeclampsia. Obstet. Gynecol. Sci. 2013, 56, 2-7. [CrossRef]

16. Hotamisligil, G.S.; Shargill, N.S.; Spiegelman, B.M. Adipose expression of tumor necrosis factor- $\alpha$ : Direct role in obesity-linked insulin resistance. Science 1993, 259, 87-91. [CrossRef]

17. Shah, A.; Mehta, N.; Reilly, M.P. Adipose inflammation, insulin resistance, and cardiovascular disease. JPEN J. Parenter. Enteral Nutr. 2008, 32, 638-644. [CrossRef]

18. Bartha, J.L.; Marín-Segura, P.; González-González, N.L.; Wagner, F.; Aguilar-Diosdado, M.; Hervias-Vivancos, B. Ultrasound evaluation of visceral fat and metabolic risk factors during early pregnancy. Obesity 2007, 15, 2233-2239. [CrossRef]

19. Taebi, M.; Sadat, Z.; Saberi, F.; Kalahroudi, M.A. Early pregnancy waist-to-hip ratio and risk P preeclampsia: a prospective cohort study. Hypertens. Res. 2015, 38, 80-83. [CrossRef]

20. De Souza, L.R.; Kogan, E.; Berger, H.; Alves, J.G.; Lebovic, G.; Retnakaran, R.; Maguire, J.L.; Ray, J.G. Abdominal adiposity and insulin resistance in early pregnancy. J. Obstet. Gynaecol. Can. 2014, 36, 969-975. [CrossRef]

21. Zhang, S.; Folsom, A.R.; Flack, J.M.; Liu, K. Body fat distribution before pregnancy and gestational diabetes: findings from coronary artery risk development in young adults (CARDIA) study. BMJ 1995, 311, 1139-1140. [CrossRef] [PubMed]

22. Rabe, K.; Lehrke, M.; Parhofer, K.G.; Broedl, U.C. Adipokines and insulin resistance. Mol. Med. 2008, 14, 741-751. [CrossRef] [PubMed]

23. Maurizi, G.; Babini, L.; Della Guardia, L. Potential role of microRNAs in the regulation of adipocytes liposecretion and adipose tissue physiology. J. Cell. Physiol. 2018, 233, 9077-9086. [CrossRef] [PubMed]

24. Barden, A. Pre-eclampsia: contribution of maternal constitutional factors and the consequences for cardiovascular health. Clin. Exp. Pharmacol. Physiol. 2006, 33, 826-830. [CrossRef] [PubMed]

25. Lopez-Jaramillo, P.; Barajas, J.; Rueda-Quijano, S.M.; Lopez-Lopez, C.; Felix, C. Obesity and preeclampsia: Common pathophysiological mechanisms. Front. Physiol. 2018, 9, 1838. [CrossRef] [PubMed]

26. Weissgerber, T.L.; Mudd, L.M. Preeclampsia and diabetes. Curr. Diab. Rep. 2015, 15, 9. [CrossRef]

27. Chen, C.-Y.; Abell, A.M.; Moon, Y.S.; Kim, K.-H. An advanced glycation end product (AGE)-receptor for AGEs (RAGE) axis restores adipogenic potential of senescent preadipocytes through modulation of p53 protein function. J. Biol. Chem. 2012, 287, 44498-44507. [CrossRef] 
28. Nativel, R.; Marimoutou, M.; Thon-Hon, V.G.; Guanasekaran, M.K.; Andries, J.; Stanislas, G.; Da Silva, C.R.; Césari, M.; Iwema, T.; Gasque, P.; et al. Soluble HMGB1 is a novel adipokine stimulating IL-6 secretion through RAGE receptor in SW872 preadipocyte cell line: Contribution to chronic inflammation in fat tissue. PLOS ONE 2013, 8, e76039. [CrossRef]

29. Tanaka, N.; Yonekura, H.; Yamagishi, S.; Fujimori, H.; Yamamoto, Y.; Yamamoto, H. The receptor for advanced glycation end products is induced by the glycation products themselves and tumor necrosis factor- $\alpha$ through nuclear factor-kB, and by $17 \beta$-estradiol through Sp-1 in human vascular endothelial cells. J. Biol. Chem. 2000, 275, 25781-25790. [CrossRef]

30. Fujiya, A.; Nagasaki, H.; Seino, Y.; Okawa, T.; Kato, J.; Fukami, A.; Himeno, T.; Uenishi, E.; Tsunekawa, S.; Kamiya, H.; et al. The role of S100B in the interaction between adipocytes and macrophages. Obesity 2014, 22, 371-379. [CrossRef]

31. Son, K.H.; Son, M.; Ahn, H.; Oh, S.; Yum, Y.; Choi, C.H.; Park, K.Y.; Byun, K. Age-related accumulation of advanced glycation end-products-albumin, $\mathrm{S} 100 \beta$, and the expressions of advanced glycation end product receptor differ in visceral and subcutaneous fat. Biochem. Biophys. Res. Commun. 2016, 477, 271-276. [CrossRef] [PubMed]

32. Wu, L.-Z.; Xiao, X.-M. Evaluation of the effects of Uncaria rhynchophylla alkaloid extract on LPS-induced preeclamsia symptoms and inflammation in pregnant rat model. Braz. J. Med. Biol. Res. 2019, 52, e8273. [CrossRef] [PubMed]

33. Yamamoto, Y.; Harashima, A.; Saito, H.; Tsuneyama, K.; Munesue, S.; Motoyoshi, S.; Han, D.; Watanabe, T.; Asano, M.; Takasawa, S.; et al. Septic shock is associated with receptor for advanced glycation end products ligation of LPS. J. Immunol. 2011, 186, 3248-3257. [CrossRef] [PubMed]

34. Gasparotto, J.; Ribeiro, C.T.; Bortolin, R.C.; Somensi, N.; Fernandes, H.S.; Teixeira, A.A.; Guasselli, M.O.R.; Agani, C.A.J.O.; Souza, N.C.; Grings, M.; et al. Anti-RAGE antibody selectively blocks acute systemic inflammatory responses to LPS in serum, liver, CSF and striatum. Brain Behav. Immun. 2017, 62, 124-136. [CrossRef]

35. Ramsgaard, L.; Englert, J.M.; Manni, M.L.; Milutinovic, P.S.; Gefter, J.; Tobolewski, J.; Crum, L.; Coudriet, G.M.; Piganelli, J.; Zamora, R.; et al. Lack of the receptor for advanced glycation end-products attenuates E. coli pneumonia in mice. PLOS ONE 2011, 6, e20132. [CrossRef]

36. Rineiro, C.T.; Gasparotto, J.; Teixeira, A.A.; Portela, L.V.C.; Flores, V.N.L.; Moreira, J.C.F.; Gelain, D.P. Immune neutralization of the receptor for advanced glycation end products reduce liver oxidative damage induced by an acute systemic injection of lipopolysaccharide. J. Biochem. 2018, 163, 515-523.

37. Wang, L.; Wu, J.; Guo, X.; Huang, X.; Huang, Q. RAGE plays a role in LPS-induced NF- $\mathrm{kB}$ activation and endothelial hyperpermeability. Sensors 2017, 17, 722. [CrossRef]

38. Li, Y.; Wu, R.; Zhao, S.; Cheng, H.; Ji, P.; Yu, M.; Tian, Z. RAGE/NF-kB pathway mediates lipopolysaccharide-induced inflammation in alveolar type I epithelial cells isolated from neonate rats. Inflammation 2014, 37, 1623-1629. [CrossRef]

39. Umesawa, M.; Kobashi, G. Epidemiology of hypertensive disorders in pregnancy: Prevalence, risk factors, predictors and prognosis. Hypertens. Res. 2017, 40, 213-220. [CrossRef]

40. Wang, Z.; Wang, Z.; Wang, L.; Qiu, M.; Wang, Y.; Hou, X.; Guo, Z.; Wang, B. Hypertensive disorders during pregnancy and risk of type 2 diabetes in later life: a systematic review and meta-analysis. Endocrine 2017, 55, 809-821. [CrossRef]

41. Sohlberg, S.; Stephansson, O.; Cnattingius, S.; Wikström, A.-K. Maternal body mass index, height, and risks of preeclampsia. Am. J. Hypertens. 2012, 25, 120-125. [CrossRef] [PubMed]

42. Lim, C.C.; Mahmood, T. Obesity in pregnancy. Best Pract. Res. Clin. Obstet. Gynaecol. 2015, 29, 309-319. [CrossRef] [PubMed]

43. Lutsiv, O.; Mah, J.; Beyene, J.; McDonald, S.D. The effects of morbid obesity on maternal and neonatal health outcomes: a systematic review and meta-analyses. Obes. Rev. 2015, 16, 531-546. [CrossRef] [PubMed]

44. Mission, J.F.; Marshall, N.E.; Caughey, A.B. Pregnancy risks associated with obesity. Obstet. Gynecol. Clin. North Am. 2015, 42, 335-353. [CrossRef]

45. Maclnnis, N.; Woolcott, C.G.; McDonald, S.; Kuhle, S. Population attributable risk fractions of maternal overweight and obesity for adverse perinatal outcomes. Sci. Rep. 2016, 6, 22895. [CrossRef]

46. Marchi, J.; Berg, M.; Dencker, A.; Olander, E.K.; Begley, C. Risks associated with obesity in pregnancy, for the mother and baby: a systematic review of reviews. Obes. Rev. 2015, 16, 621-638. [CrossRef] 
47. Santangeli, L.; Sattar, N.; Huda, S.S. Impact of maternal obesity on perinatal and childhood outcomes. Best Pract. Res. Clin. Obstet. Gynaecol. 2015, 29, 438-448. [CrossRef]

48. Segovia, S.A.; Vickers, M.H.; Gray, C.; Reynolds, C.M. Maternal obesity, inflammation, and developmental programming. BioMed Res. Int. 2014, 2014, 418975. [CrossRef]

49. Khodabandehloo, H.; Gorgani-Firuzjaee, S.; Panahi, G.; Meshkani, R. Molecular and cellular mechanisms linking inflammation to insulin resistance and $\beta$-cell dysfunction. Transl. Res. 2016, 167, 228-256. [CrossRef]

50. Luo, Y.; Liu, M. Adiponectin: a versatile player of innate immunity. J. Mol. Cell Biol. 2016, 8, 120-128. [CrossRef]

51. Eder, K.; Baffy, N.; Falus, A.; Fulop, A.K. The major inflammatory mediator interleukin-6 and obesity. Inflamm. Res. 2009, 58, 727-736. [CrossRef] [PubMed]

52. Ouchi, N.; Parker, J.L.; Lugus, J.J.; Walsh, K. Adipokines in inflammation and metabolic disease. Nat. Rev. Immunol. 2011, 11, 85-97. [CrossRef] [PubMed]

53. Kulyté, A.; Belarbi, Y.; Lorente-Cebrián, S.; Bambace, C.; Arner, E.; Daub, C.O.; Hedén, P.; Rydén, M.; Mejhert, N.; Arner, P. Additive effects of microRNAs and transcription factors on CCL2 production in human white adipose tissue. Diabetes 2014, 63, 1248-1258. [CrossRef] [PubMed]

54. Sachs, U.J.; Chavakis, T.; Fung, L.; Lohrenz, A.; Bux, J.; Reil, A.; Ruf, A.; Santoso, S. Human alloantibody anti-Mart interferes with Mac-1-dependent leukocyte adhesion. Blood 2004, 104, 727-734. [CrossRef]

55. Masuda, N.; Tsujinaka, H.; Hirai, H.; Yamashita, M.; Ueda, T.; Ogata, N. Effects of concentration of amyloid $\beta(\mathrm{A} \beta)$ on viability of cultured retinal pigment epithelial cells. BMC Ophthalmol. 2019, 19, 70. [CrossRef]

56. Rong, L.L.; Gooch, C.; Szabolcs, M.; Herold, K.C.; Lalla, E.; Hays, A.P.; Yan, S.F.; Yan, S.S.; Schmidt, A.M. RAGE: a journey from the complications of diabetes to disorders of nervous system - striking a fine balance between injury and repair. Restor. Neurol. Neurosci. 2005, 23, 355-365.

57. Zhang, Z.; Yang, L.; Lei, L.; Chen, R.; Chen, H.; Zhang, H. Glucagon-like peptide-1 attenuates advanced oxidation protein product-mediated damage in islet microvascular endothelial cells partly through the RAGE pathway. Int. J. Mol. Med. 2016, 38, 1161-1169. [CrossRef]

58. Ruan, B.H.; Li, X.; Winkler, A.R.; Cunningham, K.M.; Kuai, J.; Greco, R.M.; Nocka, K.H.; Fitz, L.J.; Wright, J.F.; Pittman, D.D.; et al. Complement C3a, CpG oligos, and DNA/C3a complex stimulate IFN- $\alpha$ production in a receptor for advanced glycation end product-dependent manner. J. Immunol. 2010, 185, 4213-4222. [CrossRef]

59. He, M.; Kubo, H.; Morimoto, K.; Fujino, N.; Suzuki, T.; Takahasi, T.; Yamada, M.; Yamaya, M.; Maekawa, T.; Yamamoto, Y.; et al. Receptor for advanced glycation end products binds to phosphatidylserine and assists in the clearance of apoptotic cells. EMBO Rep. 2011, 12, 358-364. [CrossRef]

60. Yonekura, H.; Yamamoto, Y.; Sakurai, S.; Petrova, R.G.; Abedin, M.d.J.; Li, H.; Yasui, K.; Takeuchi, M.; Makita, Z.; Takasawa, S.; et al. Novel splice variants of the receptor for advance glycation end-products expressed in human vascular endothelial cells pericytes, and their putative roles in diabetes-induced vascular injury. Biochem. J. 2003, 370, 1097-1109. [CrossRef]

61. Harashima, A.; Yamamoto, Y.; Cheng, C.; Tsuneyama, K.; Myint, K.M.; Takeuchi, A.; Yoshimura, K.; Li, H.; Watanabe, T.; Takasawa, S.; et al. Identification of mouse orthologue of endogenous secretory receptor for advanced glycation end-products: structure, function and expression. Biochem. J. 2006, 396, 109-115. [CrossRef] [PubMed]

62. Kwon, J.-H.; Kim, Y.-H.; Kwon, J.-Y.; Park, Y.-W. Clinical significance of serum sRAGE and esRAGE in women with normal pregnancy and preeclampsia. J. Perinat. Med. 2011, 39, 507-513. [CrossRef] [PubMed]

63. Cooke, C.L.; Brockelsby, J.C.; Baker, P.N.; Davidge, S.T. The receptor for advanced glycation end products (RAGE) is elevated in women with preeclampsia. Hypertens. Pregnancy 2003, 22, 173-184. [CrossRef] [PubMed]

64. Xiao, W.; Hodge, D.R.; Wang, L.; Yang, X.; Zhang, X.; Farrar, W.L. Co-operative functions between nuclear factors NFKB and CCAT/enhancer-binding protein- $\beta(C / E B P-\beta)$ regulate the IL-6 promoter in autocrine human prostate cancer cells. Prostate 2004, 61, 354-370. [CrossRef]

65. Rajaiya, J.; Sadeghi, N.; Chodosh, J. Specific NFкB subunit activation and kinetics of cytokine induction in adenoviral keratitis. Mol. Vis. 2009, 15, 2879-2889.

66. Kay, A.M.; Simpson, C.L.; Stewart, J., Jr. A. The role of AGE/RAGE signaling in diabetes-mediated vascular calcification. J. Diabetes Res. 2016, 2016, 6809703. [CrossRef] 
67. Naruse, K.; Akasaka, J.; Shigemitsu, A.; Tsunemi, T.; Koike, N.; Yoshimoto, C.; Kobayashi, H. Involvement of visceral adipose tissue in immunological modulation of inflammatory cascade in preeclampsia. Mediators Inflamm. 2015, 2015, 325932. [CrossRef]

68. Uchiyama, T.; Ota, H.; Itaya-Hironaka, A.; Shobatake, R.; Yamauchi, A.; Sakuramoto-Tsuchida, S.; Makino, M.; Kimura, H.; Takeda, M.; Ohbayashi, C.; et al. Up-regulation of selenoprotein P and HIP/PAP mRNAs in hepatocytes by intermittent hypoxia via down-regulation of miR-203. Biochem. Biophys. Rep. 2017, 11, 130-137. [CrossRef]

69. Ntambi, J.M.; Buhrow, S.A.; Kaestner, K.H.; Christy, R.J.; Sibley, E.; Kelly Jr., T.J.; Lane, M.D. Differentiation-induced gene expression in 3T3-L1 preadipocytes. Characterization of a differentially expressed gene encoding stearoyl-CoA desaturase. J. Biol. Chem. 1988, 263, 17291-17300.

70. Uchiyama, T.; Itaya-Hironaka, A.; Yamauchi, A.; Makino, M.; Sakuramoto-Tsuchida, S.; Shobatake, R.; Ota, H.; Takeda, M.; Ohbayashi, C.; Takasawa, S. Intermittent hypoxia up-regulates CCL2, RETN, and TNF $\alpha$ mRNAs in adipocytes via down-regulation of miR-452. Int. J. Mol. Sci. 2019, 20, 1960. [CrossRef]

71. Ota, H.; Tamaki, S.; Itaya-Hironaka, A.; Yamauchi, A.; Sakuramoto-Tsuchida, S.; Morioka, T.; Takasawa, S.; Kimura, H. Attenuation of glucose-induced insulin secretion by intermittent hypoxia via down-regulation of CD38. Life Sci. 2012, 90, 206-211. [CrossRef] [PubMed]

72. Ota, H.; Itaya-Hironaka, A.; Yamauchi, A.; Sakuramoto-Tsuchida, S.; Miyaoka, T.; Fujimura, T.; Tsujinaka, H.; Yoshimoto, K.; Nakagawara, K.; Tamaki, S.; et al. Pancreatic $\beta$ cell proliferation by intermittent hypoxia via up-regulation of Reg family genes and HGF gene. Life Sci. 2013, 93, 664-672. [CrossRef] [PubMed]

73. Nakagawa, K.; Takasawa, S.; Nata, K.; Yamauchi, A.; Itaya-Hironaka, A.; Ota, H.; Yoshimoto, K.; Sakuramoto-Tsuchida, S.; Miyaoka, T.; Takeda, M.; et al. Prevention of Reg I-induced $\beta$-cell apoptosis by IL-6/dexamethasone through activation of HGF gene regulation. Biochim Biophys Acta 2013, 1833, 2988-2995. [CrossRef] [PubMed]

74. Yamauchi, A.; Itaya-Hironaka, A.; Sakuramoto-Tsuchida, S.; Takeda, M.; Yoshimoto, K.; Miyaoka, T.; Fujimura, T.; Tsujinaka, H.; Tsuchida, C.; Ota, H.; et al. Synergistic activations of REG I $\alpha$ and REG I $\beta$ promoters by IL-6 and glucocorticoids through JAK/STAT pathway in human pancreatic $\beta$ cells. J. Diabetes Res. 2015, 2015, 173058. [CrossRef]

75. Fujimura, T.; Fujimoto, T.; Itaya-Hironaka, A.; Miyaoka, T.; Yoshimoto, K.; Yamauchi, A.; Sakuramoto-Tsuchida, S.; Kondo, S.; Takeda, M.; Tsujinaka, H.; et al. Interleukin-6/STAT pathway is responsible for the induction of gene expression of REG I $\alpha$, a new auto-antigen in Sjögren's syndrome patients, in salivary duct epithelial cells. Biochem. Biophys. Rep. 2015, 2, 69-74. [CrossRef]

76. Tsujinaka, H.; Itaya-Hironaka, A.; Yamauchi, A.; Sakuramoto-Tsuchida, S.; Ota, H.; Takeda, M.; Fujimura, T.; Takasawa, S.; Ogata, N. Human retinal pigment epithelial cell proliferation by the combined stimulation of hydroquinone and advanced glycation end-products via up-regulation of VEGF gene. Biochem. Biophys. Rep. 2015, 2, 123-131. [CrossRef]

77. Tsuchida, C.; Sakuramoto-Tsuchida, S.; Takeda, M.; Itaya-Hironaka, A.; Yamauchi, A.; Misu, M.; Shobatake, R.; Uchiyama, T.; Makino, M.; Pujol-Autonell, I.; et al. Expression of REG family genes in human inflammatory bowel diseases and its regulation. Biochem. Biophys. Rep. 2017, 12, 198-205. [CrossRef]

78. Tsujinaka, H.; Itaya-Hironaka, A.; Yamauchi, A.; Sakuramoto-Tsuchida, S.; Shobatake, R.; Makino, M.; Masuda, N.; Hirai, H.; Takasawa, S.; Ogata, N. Statins decrease vascular epithelial growth factor expression via down-regulation of receptor for advanced glycation end-products. Heliyon 2017, 3, e00401. [CrossRef]

79. Tohma, Y.; Dohi, Y.; Shobatake, R.; Uchiyama, T.; Takeda, M.; Takasawa, S.; Tanaka, Y.; Ohgushi, H. Reg gene expression in periosteum after fracture and its in vitro induction triggered by IL-6. Int. J. Mol. Sci. 2017, 18, 2257. [CrossRef]

80. Shobatake, R.; Takasawa, K.; Ota, H.; Itaya-Hironaka, A.; Yamauchi, A.; Sakuramoto-Tsuchida, S.; Uchiyama, T.; Makino, M.; Sugie, K.; Takasawa, S.; et al. Up-regulation of POMC and CART mRNAs by intermittent hypoxia via GATA transcription factors in human neuronal cells. Int. J. Biochem. Cell Biol. 2018, 95, 100-107. [CrossRef]

81. Kyotani, Y.; Itaya-Hironaka, A.; Yamauchi, A.; Sakuramoto-Tsuchida, S.; Makino, M.; Takasawa, S.; Yoshizumi, M. Intermittent hypoxia-induced epiregulin expression by IL-6 production in human coronary artery smooth muscle cells. FEBS Open Bio 2018, 8, 868-876. [CrossRef] [PubMed] 
82. Takasawa, S.; Tsuchida, C.; Sakuramoto-Tsuchida, S.; Takeda, M.; Itaya-Hironaka, A.; Yamauchi, A.; Misu, M.; Shobatake, R.; Uchiyama, T.; Makino, M.; et al. Expression of human REG family genes in inflammatory bowel disease and their molecular mechanism. Immunol. Res. 2018, 66, 800-805. [CrossRef] [PubMed]

83. Yoshimoto, K.; Fujimoto, T.; Itaya-Hironaka, A.; Miyaoka, T.; Sakuramoto-Tsuchida, S.; Yamauchi, A.; Takeda, M.; Kasai, T.; Nakagawara, K.; Nonomura, A.; et al. Involvement of autoimmunity to REG, a regeneration factor, in patients with primary Sjögren's syndrome. Clin. Exp. Immunol. 2013, 174, 1-9. [CrossRef] [PubMed]

84. Murakami-Kawaguchi, S.; Takasawa, S.; Onogawa, T.; Nata, K.; Itaya-Hironaka, A.; Sakuramoto-Tsuchida, S.; Yamauchi, A.; Ota, H.; Takeda, M.; Kato, M.; et al. Expression of Ins1 and Ins2 genes in mouse fetal liver. Cell Tissue Res. 2014, 355, 303-314. [CrossRef]

85. Shobatake, R.; Itaya-Hironaka, A.; Yamauchi, A.; Makino, M.; Sakuramoto-Tsuchida, S.; Uchiyama, T.; Ota, H.; Takahashi, N.; Ueno, S.; Sugie, K.; et al. Intermittent hypoxia up-regulates gene expressions of peptide YY (PYY), glucagon-like peptide-1 (GLP-1), and neurotensin (NTS) in enteroendocrine cells. Int. J. Mol. Sci. 2019, 20, 1849. [CrossRef]

(C) 2019 by the authors. Licensee MDPI, Basel, Switzerland. This article is an open access article distributed under the terms and conditions of the Creative Commons Attribution (CC BY) license (http://creativecommons.org/licenses/by/4.0/). 